\title{
Determination of root properties of saplings belong to two boxwood species (Buxus sempervirens and Buxus balearica) by image processing technique
}

\author{
Ömer Sarı (D) 1*, Fisun Gürsel Çelikel (D)2 \\ ${ }^{1}$ Black Sea Agricultural Research Institute, Samsun-Turkey \\ ${ }^{2}$ Ondokuz Mayıs University, Faculty of Agriculture, Department of Horticulture, Samsun-Turkey
}

\section{ABSTRACT}

The study was carried out to determine the root architectural characteristics of the one-year saplings of two species of boxwood (Buxus sempervirens L. and Buxus balearica Lam.), which are endangered and natural plants of Turkey, in the greenhouse environment using the WinRhizo root analysis program and scanner. Total root length $(\mathrm{cm})$, root surface area $\left(\mathrm{cm}^{2}\right)$, root volume $\left(\mathrm{cm}^{3}\right)$, average root diameter $(\mathrm{mm})$, number of tips, number of forks and number of root crossings were determined in the study.

According to the results of the study, the increase in temperature and decrease in humidity values in the second year of both species were effective on the root architectural features. As a result of this effect, the second year root length $(3810 \mathrm{~cm})$, number of root tips (2299), number of forks (7007) and number of root crossings (696) increased, root diameter (1.4 $\mathrm{mm})$, root surface area $\left(2158 \mathrm{~cm}^{2}\right)$ and root volume $\left(8 \mathrm{~cm}^{3}\right)$ decreased. As a result, it has been concluded that species can make changes in their root parameters to adapt to different conditions and their adaptability is high. In general, the best results in root architectural parameters were obtained from Buxus balearica on the basis of species.
\end{abstract}

\section{ARTICLE HISTORY}

Received: 12 April 2021

Accepted: 08 June 2021

\section{KEYWORDS}

Buxus sempervirens

Buxus balearica

Root diameter

Root surface area

Root volume

\section{* CORRESPONDING}

omer.sari@tarim.gov.tr

\section{Introduction}

Buxus L. contains about 100 species in two main diversity centers, throughout the Caribbean-Latin America and Asia, and a small proportion in Africa. The Mediterranean basin in our country includes the distribution areas of Buxus sempervirens L. and Buxus balearica Lam. Buxus sempervirens is predominantly distributed in the Black Sea and Marmara Regions, while Buxus balearica only occurs in the Mediterranean region. These species grow slowly (Köhler, 2007; Sarı and Çelikel, 2019). Boxwood species are in the form of an evergreen shrub or tree. Buxus balearica Lam. is distinguished from $B$. sempervirens $\mathrm{L}$. by having hairy young shoots, completely whitish wood and larger leaves. There is no limiting factor in terms of ecological demands in the cultivation of boxwoods. In addition, boxwoods show a better development in nutrient-rich, permeable moist soils (Gökmen, 1977; Kayacık, 1981; Davis, 1982). They are used as hedge plants, potted plants or for various decorative purposes in landscape areas. Today, the importance of the versatile use of boxwoods apart from its use as wood has started to be understood (Larson, 1996; Türkyılmaz, 2004; Sarı and Çelikel, 2019). Root growth of pot-grown plants is an essential element in overall plant performance (Wraith, 1998). The priority in plant development has always been in root development. Aboveground development of plants with successful root development is also successful (Adams and Moore, 1983).
Techniques such as plant image analysis software that can be easier, faster, reproducible and more descriptive of root growth have been developed. Although most of these techniques are applicable to field systems, they can also be used to examine plants grown in pots (Judd et al., 2015). Root architecture features can be used to predict yield, and understanding the development of root architectural features is crucial as it indicates plant suitability (Bucksch et al., 2014). It is very difficult to examine the structure of the root under the ground due to its nature. For this reason, the number of studies on the phenotypic characteristics of the root is quite low. Detailed examinations can be made on root structures using digital imaging systems developed in recent years (Paez-Garcia et al., 2015).

In this study, the root architectural features of one-year saplings of two species of boxwood (B. sempervirens L. and B. balearica Lam.) grown in the greenhouse, which are natural but endangered plants of Turkey, were examined.

\section{Materials and methods}

In this study, one-year saplings of $B$. sempervirens and $B$. balearica species, were used. The research was conducted in the Black Sea Agricultural Research Institute.

\subsection{Plant material}

Cuttings belonging to Buxus sempervirens and Buxus balearica species were planted in rooting medium in 
November. Rooted cuttings were removed in April. Newly rooted boxwood saplings were transferred to pots $(2 \mathrm{~L})$. In the study, plants with a sapling length of about 10-12 cm were used in both species. In both species, sufficient number of plants ( 90 pots/species) were obtained for the experiment. A mixture of peat+perlite (3 parts peat+1-part perlite) was used for planting the saplings. The study was carried out for two years in 2019 and 2020 (Figure 1).
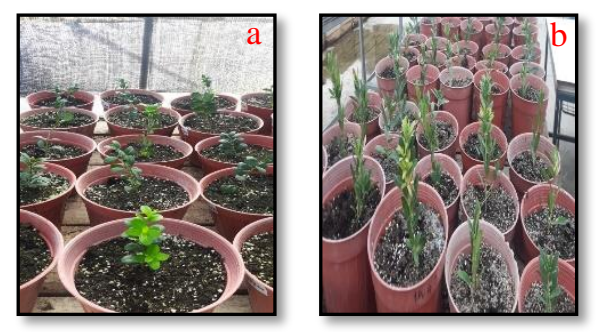

Figure 1. General view of plants transferred to pots (a: Buxus sempervirens, b: Buxus balearica).

While the average temperature inside the greenhouse was $27.6^{\circ} \mathrm{C}$ in 2019 , the average temperature was $32^{\circ} \mathrm{C}$ in 2020 . The second year was drier than the first year, therefore, while the temperature values increased, the humidity values decreased (Figure 2). In addition, the number of sunny days in 2020 is more than 2019. During the trial period in 2019 , the total sunshine duration was 1010 hours, while in 2020 it was 1123 hours in total (Figure 2).

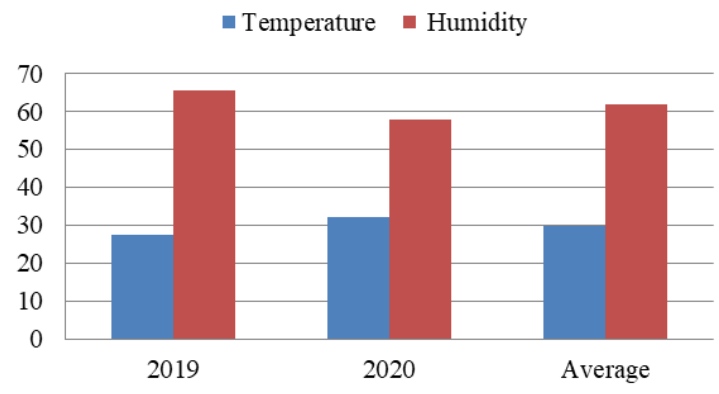

Figure 2. Temperature and humidity values in the greenhouse.

In November 2019 and 2020, after the plants were taken out of the pots, measurements were made to determine their root properties. In the greenhouse environment where the experiment was established, a canopy providing $70 \%$ shade was used. Routine cultural procedures were applied to the plants (Figure 1).

\subsection{Rooting potential and phenotypic root architecture measurements}

In plants of main cultivars to be controlled-hybridized, male A study was conducted in 2019 and 2020 to determine the root development of rooting cuttings of and Buxus balearica species. WinRhizo root analysis program (ver. 2013, Regent Instruments, QC, Canada) was used to examine the root architecture.

In the study, 5 plants were selected from each repetition. A total of 30 plants of both species were determined. Plant roots removed from the pots were carefully washed and dried with paper towels (Figure 3).

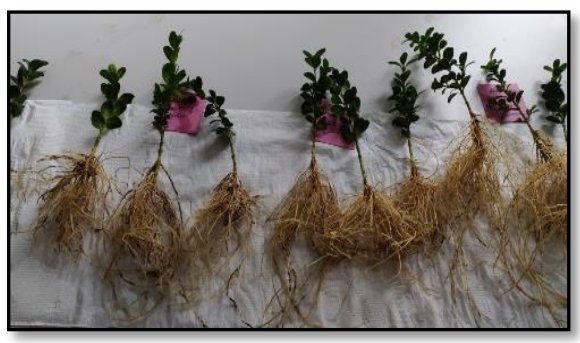

Figure 3. Plants prepared for root architecture measurement.

After drying, the roots, which were ready for scanning, were placed on the scanner (Epson Expression 10000XL, Epson America Inc., Long Beach, CA, USA) and scanned in three dimensions with the help of a computer (Figure 4, Figure 5, Figure 6).
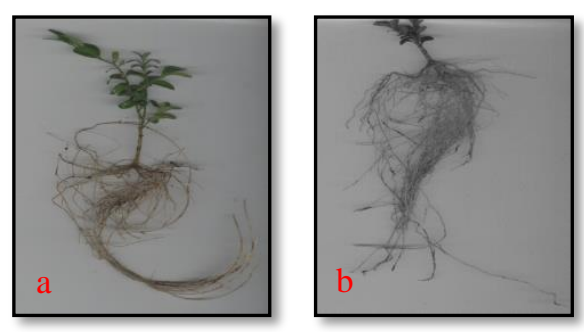

Figure 4. Root architecture view of B. sempervirens in 2019 (a) and 2020 (b).
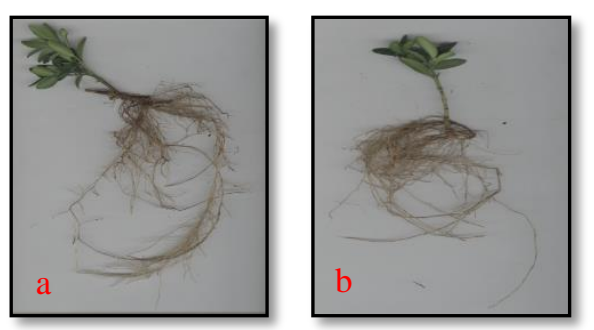

Figure 5. Root architecture view of B. balearica in 2019 (a) and 2020 (b).

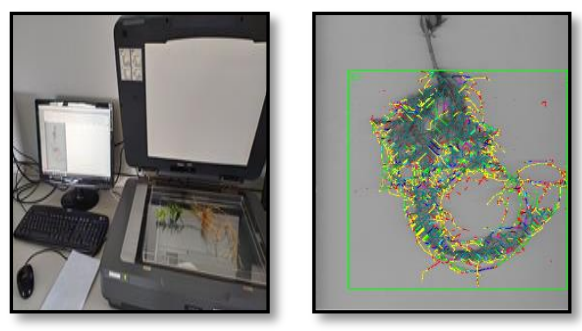

Figure 6. 3D scan images of boxwood roots.

The following parameters, which reveal the root structure and rooting levels in boxwood species in detail, were examined with the WinRhizo program.

a. Total root length $(\mathrm{cm})$ : The total length of all roots regardless of their diameter, including the fringe roots in capillary form, was determined (Sarıbaş et al., 2019) (Figure $6)$.

b. Root surface area $\left(\mathrm{cm}^{2}\right)$ : The surface area of all roots scanned in three dimensions was calculated (Sarıbaş et al., 2019) (Figure 6). 
c. Root volume $\left(\mathrm{cm}^{3}\right)$ : The net root volume was determined with the help of the program (Sarıbaş et al., 2019) (Figure 6).

d. Average root diameter $(\mathrm{mm})$ : The average root diameter was determined with the help of the program (Sarıbaş et al., 2019) (Figure 6).

e. Number of tips: The number of tips at which all root branching ends and expressing the total number of roots were determined (Sarıbaş et al., 2019) (Figure 6).

f. Number of forks: The amount of many lateral branches originating from the main root and primary lateral roots was obtained digitally (Sarıbaş et al., 2019).

g. Number of crossings: As a result of the formation and elongation of all lateral roots, the number of points where they cross each other was determined (Sarıbaş et al., 2019).

\subsection{Data Evaluation}

In the research, random plots were used with pots according to the trial design. The obtained data were analyzed in the SPSS package program, all analyzes were calculated statistically within $5 \%$ and $1 \%$ error limits, differences between applications were compared with Duncan test.

\section{Results and discussion}

The above-ground development of plants with successful root development has also been reported to be successful (Adams and Moore, 1983). They reported that qualitatively, the shape and extent of root systems affect the rate and pattern of nutrient uptake from the soil (Barley, 1970). In B. sempervirens and $B$. balearica species, no difference was detected in both years in terms of year, species and species * year interactions regarding the total root length. In both species, the highest value was obtained from the second year (4524 and $5096 \mathrm{~cm}$ ) (Table 1). Years did not affect root lengths, but first year root length values were lower than second year root length values in both species. Karaağaç et al. (2019) found that the total root length values in pepper genotypes belonging to Capsicum species showed a distribution between $519.9 \mathrm{~cm}-1109.5 \mathrm{~cm}$. Similar to the previous researches, the total root length values differed between species and years, but the differences were not statistically significant in our study (Table 1).

Table 1. Total root length $(\mathrm{cm})$ values of $B$. sempervirens and $B$. balearica species by years.

\begin{tabular}{lccc}
\hline Species & \multicolumn{3}{c}{ Year } \\
\cline { 2 - 4 } & 2019 & 2020 & Average \\
\hline B. sempervirens & 3728 & 4524 & 4126 \\
B. balearica & 3753 & 5096 & 4425 \\
\hline Average & 3741 & 4810 & \\
\hline Year & $\mathrm{ns}$ & & \\
Species & $\mathrm{ns}$ & & \\
Species * Year & $\mathrm{ns}$ & & \\
\hline Significance $* *: \mathrm{p}<0.01, *: \mathrm{p}<0.05$, ns: no significance &
\end{tabular}

In $B$. sempervirens and $B$. balearica species, no difference was detected in both years in terms of year, species and species * year interaction regarding root surface area. In both species, the highest value was obtained from the first year (2454 and $3039 \mathrm{~cm}$ ) (Table 2). Root surface area values decreased in the second year in both species. The fact that the plants reduce their root surface area in the second year is an indication that they tend to decrease the root thickness and thus increase their water and nutrient intake by developing thin roots. Karaağaç et al. (2019) showed that the average root surface area values in pepper genotypes were distributed between $581.3-890.7 \mathrm{~cm}^{2}$ in their study on Capsicum species. Researchers have reached different results in their studies on different genotype. Our study supports the findings of the researchers (Table 2).

Table 2. Root surface area $\left(\mathrm{cm}^{2}\right)$ values according to years in B. sempervirens and B. balearica species.

\begin{tabular}{lccc}
\hline Species & \multicolumn{3}{c}{ Year } \\
\cline { 2 - 4 } & 2019 & 2020 & Average \\
\hline B. sempervirens & 2454 & 1988 & 2221 \\
B. balearica & 3039 & 2328 & 2684 \\
\hline Average & 2747 & 2158 & \\
\hline Year & $\mathrm{ns}$ & & \\
Species & $\mathrm{ns}$ & & \\
Species * Year & $\mathrm{ns}$ & & \\
\hline Significance **: $<<0.01, *: \mathrm{p}<0.05$, ns: no significance. &
\end{tabular}

In $B$. sempervirens and $B$. balearica species, no difference was detected in both years in terms of species and species * year interaction regarding the mean root diameter. In terms of years, a very significant difference $(p<0.01)$ was found in both species. In both species, the highest value was obtained from the first year $(2.3$ and $2.7 \mathrm{~cm}$ ) (Table 3$)$. They reported a decrease in root diameter due to moisture loss in tree species (Yang et al., 2016; Boldrin et al, 2017). The high values of root diameter negatively affect the absorption ability of the root. Sarıbs et al. (2019) reported that low average root diameter has a positive effect on the absorption ability of the root. It was reported that a high percentage of fine roots is a desirable feature for plants (Stokes et al., 2009; Pregitzer, 2002; King et al. 2002). In our study, root diameter values were inversely proportional to temperature on the basis of species. In the second year, temperature and sunny days were higher than the first year, and humidity values were lower (Figure 2). Dorairaj et al. (2020) conducted a study on Indian rhododendron (Melastoma malabathricum), Japanese rose (Hibiscus rosa-sinensis) and Christina tree (Syzygium campanulatum) and the root diameter values of the species varied between 0.54 and $2.62 \mathrm{~mm}$. The results of the study support the findings of the previous researchers (Table 3).

Table 3. Average root diameter values ( $\mathrm{mm}$ ) according to years in B. sempervirens and B. balearica species.

\begin{tabular}{lccc}
\hline Species & \multicolumn{3}{c}{ Year } \\
\cline { 2 - 4 } & 2019 & 2020 & Average \\
\hline B. sempervirens & 2.3 & 1.4 & 1.5 \\
B. balearica & 2.7 & 1.3 & 2.0 \\
\hline Average & $2.5 \mathrm{~A}$ & $1.4 \mathrm{~B}$ & \\
\hline Year & $* *$ & & \\
Species & $\mathrm{ns}$ & & \\
Species * Year & $\mathrm{ns}$ & & \\
\hline Significance $* *: \mathrm{p}<0.01, *: \mathrm{p}<0.05$, ns: no significance. &
\end{tabular}

In $B$. sempervirens and $B$. balearica species, no difference was detected in both years in terms of species and species * year interaction regarding root volume. In terms of years, a significant difference $(\mathrm{p}<0.05)$ was found in both 
species. In both species, first year values were higher than the second year (13 and $16 \mathrm{~cm}^{3}$ ) (Table 4). It has been determined that in both species, the decrease in the root volume in the second year and the amount of thick and short roots may cause. Because the plants increased the root length and decreased the root diameters with the increase in the temperature values in the second year. In the study of Sarıbaş et al. (2019), root volume values of eggplant rootstock candidates (Solanum melongena x Solanum aethiopicum) varied between 38.5 and $119.1 \mathrm{~cm}^{3}$. However, it was found that root length value of some rootstock candidates was low and root diameter value was high. They reported that the reason for the high root volume can be explained as the high amount of thick and short roots. In the studies of the researchers, they obtained different root volumes among the species. The findings of our study are similar to the findings of the other researchers (Table 4).

Table 4. Root volume $\left(\mathrm{cm}^{3}\right)$ values according to years in $B$. sempervirens and B. balearica species.

\begin{tabular}{lccc}
\hline Species & \multicolumn{3}{c}{ Year } \\
\cline { 2 - 4 } & 2019 & 2020 & Average \\
\hline B. sempervirens & 13 & 7 & 10 \\
B. balearica & 16 & 9 & 13 \\
\hline Average & $15 \mathrm{~A}$ & $8 \mathrm{~B}$ & \\
\hline Year & $*$ & & \\
Species & $\mathrm{ns}$ & & \\
Species * Year & $\mathrm{ns}$ & & \\
\hline Significance $* *: \mathrm{p}<0.01, *: \mathrm{p}<0.05$, ns: no significance. &
\end{tabular}

In $B$. sempervirens and $B$. balearica species, no difference was detected in both years in terms of species and species $x$ year interaction regarding the number of tips in the root. In terms of years, a significant difference $(p<0.05)$ was found in both species. In terms of year averages, the second year value (2299) is higher than the first year (Table 5). With the effect of sunshine duration and humidity values (Figure 2 ), while the root length increased in the second year, the number of tips in the root also increased. This result shows that the root length is directly proportional to the number of tips in both species. In the study by Sarıbas et al. (2019), the number of tips of the roots of the eggplant rootstock candidates (Solanum melongena $x$ Solanum aethiopicum) varied between 8058 and 22949. Researchers have obtained different results from different rootstocks. Similar to the researchers in our study, the reactions of different species to the years of application were different (Table 5).

Table 5. Root tips number values according to years in $B$. sempervirens and B. balearica species.

\begin{tabular}{lccc}
\hline Species & \multicolumn{3}{c}{ Year } \\
\cline { 2 - 4 } & 2019 & 2020 & Average \\
\hline B. sempervirens & 2740 & 2252 & 2496 \\
B. balearica & 437 & 2346 & 1392 \\
\hline Average & $1589 \mathrm{~A}$ & $2299 \mathrm{~B}$ & \\
\hline Year & $*$ & & \\
Species & $\mathrm{ns}$ & & \\
Species * Year & $\mathrm{ns}$ & & \\
\hline Significance & $* *: \mathrm{p}<0.01, *: \mathrm{p}<0.05$, ns: no significance.
\end{tabular}

In B. sempervirens and B. balearica species, a significant difference $(\mathrm{p}<0.01)$ was found in terms of species and species * year interaction regarding the number of forks in the root. There is a significant difference in terms of year averages $(p<0.05)$ and the highest value was obtained from the first year (7007), while the highest value (8695) was obtained from $B$. sempervirens in terms of species average (Table 6). In both species, while root length increased with temperature, the number of forks in the root increased in direct proportion. As plants are under stress, they form longer roots and root branches to reach nutrients and water. Sarıbaş et al. (2019) determined that the root forks number of eggplant rootstock candidates (Solanum melongena $x$ Solanum aethiopicum) varied between 29661 and 57226 . The researcher revealed that there is a difference between rootstock candidates in terms of the number of forks in the root. Therefore, in our study, the number of forks in the root of both species showed a difference and increased in the second year. Other than the effects of climatic factors on the differences between the years, the species has also had an effect (Table 6).

Table 6. The number of forks in the root according to years in B. sempervirens and B. balearica species.

\begin{tabular}{lccc}
\hline Species & \multicolumn{3}{c}{ Year } \\
\cline { 2 - 4 } & 2019 & 2020 & Average \\
\hline B. sempervirens & $10785 \mathrm{~b}$ & $6604 \mathrm{~d}$ & $8695 \mathrm{~B}$ \\
B. balearica & $2340 \mathrm{a}$ & $7409 \mathrm{c}$ & $4875 \mathrm{~A}$ \\
\hline Average & $6563 \mathrm{~A}$ & $7007 \mathrm{~B}$ & \\
\hline Year & $*$ & & \\
Species & $* *$ & & \\
Species * Year & $* *$ & & \\
\hline Significance $* *: \mathrm{p}<0.01, *: \mathrm{p}<0.05$, ns: no significance. &
\end{tabular}

In $B$. sempervirens and $B$. balearica species, a significant difference $(\mathrm{p}<0.01)$ was found in terms of species * year interaction regarding the number of root crossing. There is a significant difference in terms of year and species averages $(\mathrm{p}<0.05)$, while the highest value in terms of year average was obtained from the second year (696), the highest value was obtained from $B$. balearica species (513) in terms of average species. In both species, the number of root crossing increased in the second year (Table 7). Zou et al. (2017) in their study on three leaves (Trifoliate orange), the number of root crossing changed between 252 and 765 as a result of different applications. In our study, root crossing values of both species increased in the second year due to the stress occurring on the plant, depending on the effect of temperature and sunshine duration (Figure 2). Accordingly, it was concluded that the plants increased the number of root tips in order to increase their adaptability. The results support the researchers (Table 7).

According to the results, it is suggested that the root architectural features can vary according to years, species and climatic conditions. Both species increased the amount of water lost by the plants as the temperature increased in the second year and the humidity values decreased, and consequently, the plants desire to reach more water increased. Therefore, in order to reach more water, they increased the root length, number of tips, number of forks and number of crossings, and to increase absorption. They decreased the root diameter, root surface area and root volume. These results are an indication that species to change their root parameters to adapt to different conditions. 
Table 7. Root crossing number in B. sempervirens and $B$. balearica species according to years.

\begin{tabular}{lccc}
\hline Species & \multicolumn{3}{c}{ Year } \\
\cline { 2 - 4 } & 2019 & 2020 & Average \\
\hline B. sempervirens & $179 \mathrm{a}$ & $669 \mathrm{~b}$ & $424 \mathrm{~A}$ \\
B. balearica & $303 \mathrm{c}$ & $723 \mathrm{~b}$ & $513 \mathrm{~B}$ \\
\hline Average & $241 \mathrm{~A}$ & $696 \mathrm{~B}$ & \\
\hline Year & $*$ & & \\
Species & $*$ & & \\
Species * Year & $* *$ & & \\
\hline Significance **: $<<0.01, *$ : $<<0.05$, ns: no significance.
\end{tabular}

As a result, we suggest that it is possible to predict what the plants live by looking at plant's root architectures with imaging systems used in recent years. The results obtained are important in predicting the developmental behavior of boxwood species under different conditions. The results showed that both species have high adaptation abilities to climate changes. In future studies on plant growth, it is recommended to evaluate both above-ground and underground plant parts together. It is necessary to carry out more comprehensive studies on our boxwood species, which are the important resources of Turkey.

\section{Acknowledgment}

This study was supported by Ondokuz Mayls University (Project number: PYO.ZRT.1904.19.002).

\section{Authors' Contributions}

Ömer Sarı: Methodology, Investigation, Conceptualization, Validation, Writing original draft. Fisun Gürsel Çelikel: Methodology, Investigation, Conceptualization, Validation, Review and editing.

\section{Conflict of Interest}

The authors declare that they have no conflict of interest.

\section{References}

Adams, F., \& Moore, B. L. (1983). Chemical factors affecting root growth in subsoil horizons of coastal plain soils. Soil Science Society of America Journal, 47(1), 99-102.

Barley, K. P. (1970). The configuration of the root system in relation to nutrient uptake. In Advances in agronomy (Vol. 22, pp. 159-201). Academic Press.

Boldrin, D., Leung, A. K., \& Bengough, A. G. (2017). Correlating hydrologic reinforcement of vegetated soil with plant traits during establishment of woody perennials. Plant and Soil, 416(1), 437-451.

Bucksch, A., Burridge, J., York, L. M., Das, A., Nord, E., Weitz, J. S., \& Lynch, J. P. (2014). Image-based high-throughput field phenotyping of crop roots. Plant Physiology, 166(2), 470-486.

Davis, (1982). "Flora of Turkey and the East Aegean Islands", Volume Seven, Edinburgh at the University Pres, 22 George Sguare, Edinburgh, ISBN:0852243960, 630-632.
Dorairaj, D., Suradi, M. F., Mansor, N. S., \& Osman, N. (2020). Root architecture, rooting profiles and physiological responses of potential slope plants grown on acidic soil. PeerJ, 8, e9595.

Gökmen, H. (1977). Kapalı Tohumlular (Angiospermae) 2. Cilt. Orman Bakanlığı yayınları Sıra No. 616, Seri No. 55, Ankara, s. 38-609.

Instuments, R. (1996). WinRhizo V3. 9 Reference. Regent Instruments Inc., Quebec, Canada.

Judd, L. A., Jackson, B. E., \& Fonteno, W. C. (2015). Advancements in root growth measurement technologies and observation capabilities for container-grown plants. Plants, 4(3), 369-392.

Karaağaç, O., Kübra, T. A. Ș., Özgen, R., Kanal, A., \& Balkaya, A. (2020). Capsicum türlerinin kök yapılarının incelenmesi ve kök özellikleri yönünden karşılaştırılması. Yüzüncü Yll Üniversitesi Tarım Bilimleri Dergisi, 30(2), 266-279.

Kayacık, H. (1981). "Orman ve Park Ağaçlarımızın Özel Sistematiği”, II. Cilt Angiospermae, II. Baskı İ.Ü. Orman Fakultesi Yayınları, İstanbul, 145-148.

King, J. S., Albaugh, T. J., Allen, H. L., Buford, M., Strain, B. R., \& Dougherty, P. (2002). Below ground carbon input to soil is controlled by nutrient availability and fine root dynamics in loblolly pine. New Phytologist, 154(2), 389-398.

Köhler, E. (2007). In: Kobinski, K. (Ed.), Buxaceae. The Families and Genera of Flowering Plants. Springer, Berlin, Heidelberg, New York.

Larson, P. D. (1996). Boxwood: İts History, Cultivation, Propagation and Descriptions. Boyce, VA: Foliar Press VI.

Paez-Garcia, A., Motes, C. M., Scheible, W. R., Chen, R., Blancaflor, E.B., \& Monteros, M.J., (2015). Root traits and phenotyping strategies for plant improvement. Plants, 4, 334355.

Pregitzer, K. S. (2002). Fine roots of trees-a new perspective. New Phytologist, 154(2), 267-270.

Sarı, Ö., \& Çelikel, F. G. (2019). Türkiye'nin Şimşirleri (Buxus sempervirens ve Buxus balearica) ve Mevcut Tehditler. I. International Ornamental Plants Congress - VII. Süs Bitkileri Kongresi, 9-11 Ekim 2019, Bursa, S. 383-393.

Sarıbaş, S., Balkaya, A., Kandemir, D., \& Karaağaç, O. (2019). The phenotypic root architectures and rooting potential of local eggplant rootstocks (Solanum melongena $x$ Solanum aethiopicum). Black Sea Journal of Agriculture, 2(3), 137-145.

Stokes, A., Atger, C., Bengough, A. G., Fourcaud, T., \& Sidle, R. C. (2009). Desirable plant root traits for protecting natural and engineered slopes against landslides. Plant and Soil, 324(1), 130 .

Türkyilmaz, E. (2004). "Şimşir (Buxus sempervirens L.) Odununun Bazı Morfolojik ve Fiziksel Özellikleri", V. Ulusal Orman Fakülteleri Öğrenci Kongresi, Bildiriler Kitabı, 2. Cilt-Orman Endüstri Mühendisliği, K.T.Ü. Orman Fakültesi, Trabzon, pp.18-22.

Wraith, J. M., \& Wright, C.K. (1998). Soil water and root growth: Soil Environment and Root Growth. HortScience, 33(6), 951959.

Yang, Y., Chen, L., Li, N., \& Zhang, Q. (2016). Effect of root moisture content and diameter on root tensile properties. PLoS One, 11(3), e0151791.

Zou, Y. N., Wang, P., Liu, C. Y., Ni, Q. D., Zhang, D. J., \& Wu, Q. S. (2017). Mycorrhizal trifoliate orange has greater root adaptation of morphology and phytohormones in response to drought stress. Scientific Reports, 7(1), 1-10. 